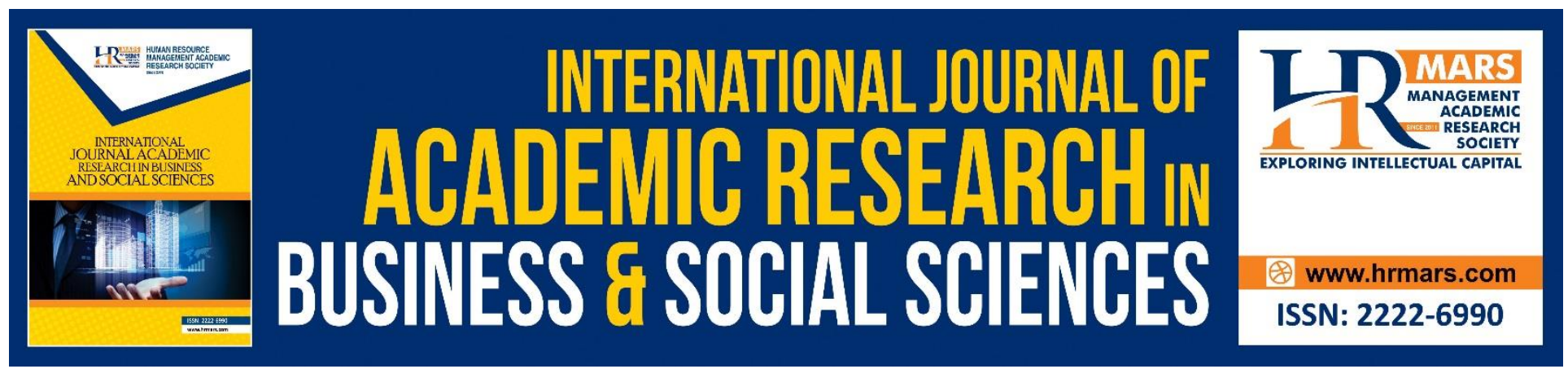

\title{
Risk Assessment: A Fight against Fraud in Nigerian Organizations
}

\author{
Imaobong Nnam, Nnajiofor Eneh
}

To Link this Article: http://dx.doi.org/10.6007/IJARBSS/v8-i7/4329

DOI: $10.6007 /$ IJARBSS/v8-i7/4329

Received: 16 May 2018, Revised: 19 June 2018, Accepted: 23 June 2018

Published Online: 29 July 2018

In-Text Citation: (Nnam \& Eneh, 2018)

To Cite this Article: Nnam, I., \& Eneh, N. (2018). Risk Assessment: A Fight against Fraud in Nigerian Organizations. International Journal of Academic Research in Business and Social Sciences, 8(7), 133-144.

Copyright: (c) 2018 The Author(s)

Published by Human Resource Management Academic Research Society (www.hrmars.com)

This article is published under the Creative Commons Attribution (CC BY 4.0) license. Anyone may reproduce, distribute, translate and create derivative works of this article (for both commercial and non-commercial purposes), subject to full attribution to the original publication and authors. The full terms of this license may be seen at: http://creativecommons.org/licences/by/4.0/legalcode

Vol. 8, No. 7, July 2018, Pg. 133 - 144

Full Terms \& Conditions of access and use can be found at http://hrmars.com/index.php/pages/detail/publication-ethics 


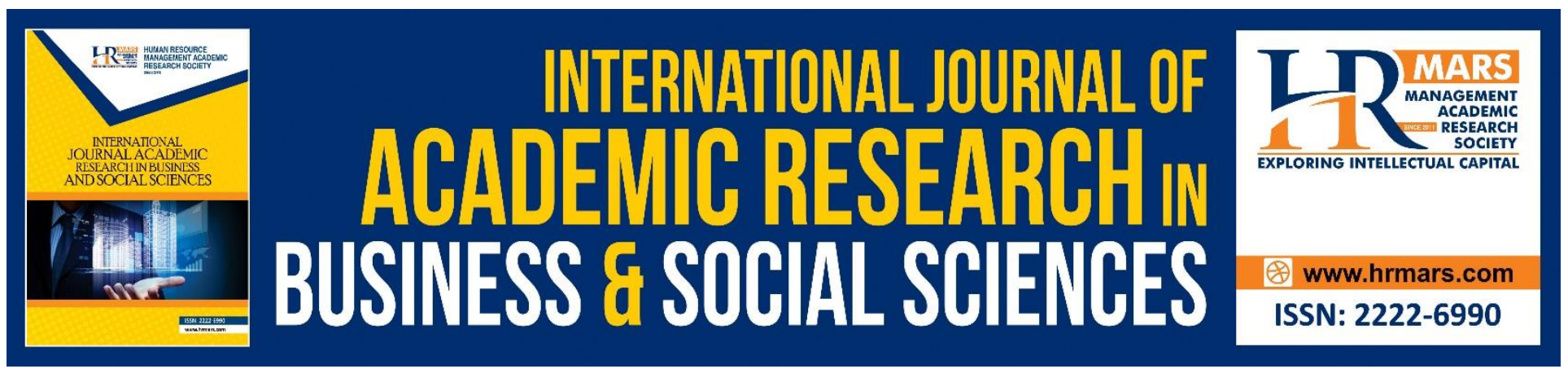

\title{
Risk Assessment: A Fight against Fraud in Nigerian Organizations
}

\author{
Nnam, Imaobong \\ Department of Accountancy, Faculty of Business Administration, University of NigeriaEnugu \\ Campus \\ Email: Ima.nnam@unn.edu.ng \\ Eneh, Nnajiofor \\ Department of Management, Faculty of Business Administration, University of Nigeria Enugu \\ Campus
}

\begin{abstract}
With the resent reforms in corporate governance requirement, risk assessment has become a prominent feature in organizational control and management. This study looks at the risk assessment practices of some selected firms in Nigeria to determine the presence and therefore the impact of this practice. The population comprised of firms listed on the stock exchange that are audited by the big four audit firms (KPMG, E\&Y, PWC \& AWD) in Nigeria. Using judgment sampling, two senior management and four internal control staff were selected. Data was collected by means of a questionnaire with response options graduated into five Likert scales. The questionnaire captured responses from questions on risk assessment practices and fraud occurrence in the organizations. Logistic regression was used to test the hypothesis and the result showed a positive and significant relationship between risk assessment and fraud in Nigerian organizations. The study provides insight into the organizational practice with reference to risk assessment. From this study, Nigerian Organizations have not imbibed the prescriptions of the resent corporate governance codes. The study, therefore, recommends that sanctions should be put in place to enforce compliance to these corporate governance codes. and attention should be paid to the appointment of board members to ensure that a vibrant audit committee is constituted.

Keywords: Risk Assessment, Corporate Governance, Fraud, Enterprise Risk Management, Internal Control.

Introduction

After the global financial crises and its devastating effects, a lot of changes were made in the reporting requirement of organizations. However, before this era, efforts had been made towards a better management of the organizations to ensure that risk and fraud are brought to its minimum. For instance, the foreign corrupt practices act of 1977 required Securities and Exchange Commission
\end{abstract}


INTERNATIONAL JOURNAL OF ACADEMIC RESEARCH IN BUSINESS AND SOCIAL SCIENCES Vol. 8, No. 7, July 2018, E-ISSN: 2222-6990 @ 2018 HRMARS

(SEC) registrants to maintain a cost-effective system of control over assets and business transactions. Risk being an important aspect of business survival cannot be overlooked. Risk in business is inevitable. A balance, therefore, has to be struck between the level of risk to undertake and expected return there off.

Following the Turn bull report of 1998, the directors are expected to conduct a review of the effectiveness of the internal control system and then report to the providers of capital. This review is expected to cover all aspects of control which include financial control, operational control compliance control and risk assessment. Risk management is recognized as an important factor of organizational survival. This can be seen in the expectation of the Turnbull report which requires listed companies to have a system of internal control in which monitoring of risk and control is an accepted process.

From the definition of internal control as a system of financial control and other controls put in place to ensure that organization are run in an efficient and effective manner, ensure the reliability of financial records, safeguard the assets and then ensure the prevention and detection of fraud (Turnbull 1999). In Turnbull's definition of internal control, a broader responsibility of the management of risk is placed on the organization's system of internal control. This definition reflects a positive move away from Cadbury's narrow focus of internal financial control Zaman (2001).

Subsequently, in Nigerian, in other to align with international best practices, the Securities and Exchange Commission (SEC) and the Corporate Affairs Commission inaugurated a committee to evaluate the weaknesses in current corporate governance practices as part of internal control practices in Nigeria and then proffer necessary changes to improve it. The report of this committee which was approved by the board of SEC centered on code of best practices and they identified the board of directors, the shareholders and the audit committee as the major players in the process. It is now left for organizations to key into this code and be compliant with international best practices.

Studies by the Economic and Financial Crimes Commission (EFCC) and Nigeria Bureau of Statistics (NBS)have shown that crime and corruption represent a huge concern for business executives in Nigeria. This study also showed that over $75 \%$ of business obstacles were caused by crimes and corruption. At the international level, organizations are not spared. Then, the smaller organizations, they are even at more risk. Huge sums are lost due to crime and corruption. The Nigerian Deposit Insurance Commission (NDIC) in 2006 reported a total of 1193 cases of fraud and forgeries in the industry with a value of 4.83 billion. Out of this amount, N2.77 bill representing $57 \%$ were expected to be lost. This report is corroborated by another report by the FITC October 2008 which showed that during the quarter a total of 480 cases of fraud and forgeries were reported (which means 19.9\% increase). During the preceding quarter the amount rose from 1.57 billion to $3.4 \mathrm{billion}$. This means an increase of $116.56 \%$.

If all these are observed within the organized sector, then the unorganized sector will be experiencing more serious challenges. In business, every organization is susceptible to failure and this potential is heightened when organizations and their management do not pay adequate attention to major business hazards. Which may be in the area of credit or liquidity, strategies, contractual difficulties and even the people and their business processes.

Poor internal control (I.C) which encompasses enterprise risk management(ERM) has been identified as a common cause of business failure. Examples include Enron, World Com andOceanic Bank, Bank PHB.. When organization experience fraud, they suffer significant losses and their reputation and 
INTERNATIONAL JOURNAL OF ACADEMIC RESEARCH IN BUSINESS AND SOCIAL SCIENCES

Vol. 8, No. 7, July 2018, E-ISSN: 2222-6990 ㄷ 2018 HRMARS

business relation declines and they may even consider bankruptcy or change of ownership. (Arens, Elder and Beasly (2006)

If corporations in Nigeria continue to face difficulties as a result of fraud perpetrated in the organizations, the attendant consequence includes lack of economic growth. For any economy to experience sustainable growth it requires a continuous investment from within and outside the economy. But when there is fear of failure, due to a high level of risk, investments will dwindle and the economy will be stagnated and for a developing economy like Nigeria, this is catastrophic.

\section{Objective of the Study}

The broad objective of this study is to examine the impact of risk assessment in Nigerian organisations.

Specifically, the study examined the presence of risk management practices in Nigerian organizations. Secondly, it investigated the impact of risk assessment as part of internal control in the prevention of fraud.

\section{Hypothesis}

Risks assessment as part of internal control is not positively and significantly related to fraud prevention in Nigerian organization.

\section{Scope of study}

This study includes all quoted companies on the Nigerian stock exchange that are audited by the big four audit firms numbering 81 as at 2014/2015.

\section{Significance of study}

Nigeria being a country which aligns with international best practices present a good case study to explore the extent of adherence and the impact of adherence to prescribed procedures on enterprises risk management. The outcome will be beneficial to management and board of directors of organizations who are supposed to implement this procedure of risk assessment. The study also contributes to the body of knowledge on ERM.

\section{Limitation of Study}

Data collected represent risk assessment procedures in organization listed on the stock exchange and are being audited by the big four audit firms. Firms not audited by the big four audit firms and those not quoted on the stock exchange are not represented. This may serve as areas for further studies. Another limitation of this study was the difficulty encountered in locating these organizations.

\section{Theoretical Review}

In a typical business, ownership is usually separated from control. This separation carries a lot of implications. One of such implications is that 'control' takes place on behalf of 'ownership'. 'Control' is an agent of 'ownership'. Because of this separation, conflict usually arises.

The agency theory as usually adopted in corporate governance studies in business focuses on the resolution of this conflict between ownership and control. Agency problem arises when the interest of the principal and that of the agent are conflicting and it is expensive for the principal to verify the actions of the agent (Shapiro, 2005). 
INTERNATIONAL JOURNAL OF ACADEMIC RESEARCH IN BUSINESS AND SOCIAL SCIENCES Vol. 8, No. 7, July 2018, E-ISSN: 2222-6990 @ 2018 HRMARS

Another problem arises when the risk appetite of the principal and the agent are different and so the agent may not perfectly act in the best interest of the principal. All these incompatibilities may lead to inefficiencies and even financial loss (Spira and Page,2002). In an effort to align these diverse interests toward achieving the organizational objective, certain mechanism of accountability is adopted through corporate governance policies with defined guideline for internal audit, risk management etc. Demidenko and McNutt (2010) posit that through ERM, the principal can be reassured that the agent is meeting with their interest through diligent and efficient behaviour. The agency theory is very popular in corporate governance researches in business and therefore has developed a definition of corporate governance that is shareholder centred (Stewart and Kent, 2006). This can be seen in the process of supervision and control which has the objective of ensuring that management acts in the best interest of the shareholders. (Pakinson 1993) as cited in Brenna \& Solomon (2008).

This shareholder focused perspective is also reflecting in most of the recent corporate governance policy statement and codes. For instance the Cadbury report of 1992, the Turnbull report of 1999, the Greenbury report of 1995, the combined code of corporate governance 2003 and 2006. All these approached corporate governance reforms from a perspective which placed shareholders wealth maximization and protection first.

\section{Empirical Review of Literature}

Several studies have been carried out since the emergence of enterprise risk management (ERM) to assess the extent of application of the new role of risk assessment. According to Stewart and Subramanian (2011) many organization have been found to have recently keyed into ERM. But with this new role, a lot more is required and more involvement is expected. In a study by Demidenko \& McNatt (2010) which was carried out to study the ethics of risk management, they found that the implementation of risk management involved a number of common challenges which ranged from the definition of risk appetite, the inclusion of RM in the organizational culture, the function of ERM to the internal audit.

From the prescription of the institute of internal auditors (IIA), it can be clearly seen that the internal auditor has a major role to play in ERM. Stewart and Kent (2006), found that there was a strong relationship between internal audit and the level of commitment to RM. However, it has been argued that the involvement of the internal auditor may have some negative effects on their primary role. Stewart and Subramania (2011) in the study to examine the impact of internal auditors' involvement in enterprise risk management, found out that internal auditors (IA)'s high involvement in ERM affects his willingness to bring before the audit committee a breakdown in the risk procedures. They also found that some IA engages in activities that may compromise their objectivity.

In Nagy \& Cenker (2002), they found that this new role of auditors was differently viewed and different objectives were perceived. A shift in the role of the auditors was agreed to have occurred but they advised that the old role should not be given up entirely.

\section{Impact of RM on Performance}

Studies have also been carried out to examine the impact of ERM in the performance of firms. Ping \& Muthuveloo (2015) examined the implementation of ERM on firm performance of companies listed publicly in Malaysia and it was found that the implementation of ERM significantly influenced firms. However, they found that other factors influenced the relationship between firm's performance and ERM. Such factors included monitoring by the Board of directors (BODs), the size of the firm and the 
complexity of the firm. In another study by Cheplel (2013) on the impact of ERM in the financial performance of banks in Kenya. It was found out that there was a positive correlative between the practice of ERM and firm performance.

In Nigeria Obalola, Akpan and Olufemi (2014) studied the relationship between ERM and organizational performance in the insurance industry, they found that there was a positive relationship between the variables (contingency reserves, shareholders' funds, gross premium and net premiums) of ERM and the performance of the firm.

From the foregoing, it can be seen that several studies have been carried out on risk assessment as part of internal control in corporate governance. Evidence from these studies nudges as to conclude that enterprises risk management is a crucial tool for organizational sustainability, therefore this study embarks on an assessment to determine if Nigerian firms are assured of sustainability stemming from this practice.

\section{Methodology}

The study adopted a descriptive research design and survey method was employed in the process of data collection. The population of the study is 3,560 staff of 81 companies quoted on the Nigerian stock exchange and are being audited by the big four audit firms in Nigeria, namely; KPMG, Akintola William Deloitte, Price Water House Coopers and Ernst and Young. The subjects for the study include the senior management and staff of the internal control department of the companies which numbered 486. These respondents were selected using judgmental sampling approach. The choice of these respondents was influenced by the fact that the big four audit firms have international affiliations, align with international best practices which makes it imperative for them to use standard practices. The members of staff of these firms were chosen because they are directly involved with their firm's internal control practices.

\section{Data Collection}

Data were collected with the use of a questionnaire which was constructed based on the requirement of section 404 of Sarbanes-Oxley (Sox) Act on internal control evaluation. The questionnaire gathered information on demographic characteristics of the respondents, risk assessment processes of the organisations and the occurrence or non-occurrence of fraud in the organizations studied.

\section{Method of Data Analysis}

The technique for the analysis was both content and statistical. With regard to content, it exposed the available information on purely descriptive, comparative and analytical grounds.

A descriptive statistics were used to analyze the organizational practices and the result was presented using tables.

Logistic regression(inferential statistics) was used to test the impact of the independent variable(risk assessment) on a categorical dependent variable (fraud)

Model specification:

The logistic regression model for the study is as follows.

Logistic regression model

$\pi \frac{\ln \left[\frac{\pi}{1-\pi}\right]=\beta_{0}+\beta_{1 x}}{\frac{\exp \left(\beta_{0}+\beta_{1 x}\right)}{1+\exp \left(\beta_{0}+\beta_{1 x}\right)}=P\left(Y=1 / X_{1}, \ldots \ldots, X_{p}\right)}$ 
INTERNATIONAL JOURNAL OF ACADEMIC RESEARCH IN BUSINESS AND SOCIAL SCIENCES

Vol. 8, No. 7, July 2018, E-ISSN: 2222-6990 @ 2018 HRMARS

Where $\mathrm{Y}=$ dependent variables (fraud)

$X_{i}=$ independent variable (risk assessment)

$\exp =$ exponential function

$\beta_{0}=$ Intercept

$\beta_{1}=$ slope

1 = constant

Because the dependent variable is not continuous, the goal of the model was to predict the likelihood that $\mathrm{Y}$ is equal to 1 (rather than 0 ).

Data Presentation and Discussion of Findings

Data presentation include demographic information, information on risk assessment, fraud occurence and test of hypothesis.

Table 1: Demography of the Respondents

\begin{tabular}{|c|c|c|c|}
\hline s/no & Items & Frequency & Percentage \% \\
\hline 1 & $\begin{array}{ll}\text { Sex: } & \\
& \text { Male } \\
& \text { Female }\end{array}$ & $\begin{array}{l}264 \\
157\end{array}$ & $\begin{array}{l}62.7 \\
37.3\end{array}$ \\
\hline 2 & $\begin{array}{l}\text { Age } \\
\text { Above } 50 \text { yrs } \\
41-50 \\
31-40 \\
21-30 \text { yrs }\end{array}$ & $\begin{array}{l}79 \\
221 \\
84 \\
37 \\
\end{array}$ & $\begin{array}{l}18.8 \\
52.5 \\
20.0 \\
8.8 \\
\end{array}$ \\
\hline 3 & $\begin{array}{l}\text { Marital status } \\
\text { Single } \\
\text { Married }\end{array}$ & $\begin{array}{l}124 \\
297\end{array}$ & $\begin{array}{l}29.5 \\
70.5\end{array}$ \\
\hline 4 & $\begin{array}{l}\text { Academic Qualification } \\
\text { HND/ } 1^{\text {st }} \text { Degree } \\
\text { Post graduate degree }\end{array}$ & $\begin{array}{l}199 \\
222\end{array}$ & $\begin{array}{l}47.3 \\
52.7\end{array}$ \\
\hline 5 & $\begin{array}{l}\text { Professional qualification } \\
\text { None } \\
\text { ICAN } \\
\text { ACE ACA } \\
\text { ACA, CISA, CISM } \\
\text { ACCA } \\
\text { ACA,CISA, ERISE } \\
\text { ACA, ACIB } \\
\text { CIBN } \\
\text { CISS, CISA } \\
\text { CRISC, ACDA, ACIB } \\
\text { ACA, ACIT, ACII } \\
\text { ACA, ACIB, ACTI }\end{array}$ & $\begin{array}{l}271 \\
52 \\
4 \\
8 \\
47 \\
11 \\
4 \\
8 \\
4 \\
4 \\
4 \\
4\end{array}$ & $\begin{array}{l}64.4 \\
12.4 \\
1.0 \\
1.9 \\
11.2 \\
2.6 \\
1.0 \\
2.0 \\
1.0 \\
1.0 \\
1.0 \\
1.0\end{array}$ \\
\hline
\end{tabular}


INTERNATIONAL JOURNAL OF ACADEMIC RESEARCH IN BUSINESS AND SOCIAL SCIENCES

Vol. 8, No. 7, July 2018, E-ISSN: 2222-6990 @ 2018 HRMARS

\begin{tabular}{|l|l|l|l|}
\hline 6 & Working experience & & \\
& $<1 \mathrm{yr}$ & 50 & 11.9 \\
& $1-5 \mathrm{yrs}$ & 92 & 21.9 \\
& $5-10 \mathrm{yrs}$ & 156 & 37.1 \\
& $10-20 \mathrm{yrs}$ & 123 & 29.2 \\
\hline 7 & Position & & \\
& Management & 134 & 31.8 \\
& Staff of internal control & 287 & 68.2 \\
\hline
\end{tabular}

\section{Source: researcher}

\section{Demography Information}

The demography report of the respondent shows that the management and staff of these sample firms consisted mostly of male (62.7\%) while the female was $32.3 \%$.

The majority of this respondent was in the age bracket of 41-50 years, (52.5\%) followed by the age bracket of $31-40$ years old (20\%) than those above 50 years (18.8\%) and finally those between $21-30$ years of age (8.8\%). Most of these people also have a postgraduate qualification (52.7\%) and $35.6 \%$ of them also belong to a professional body. Most of these respondents have worked in their respective firms mostly between 5 -10years (37.1\%) the next group has stayed between 10-20years (29.2\%), $21.9 \%$ have stayed between $1-5 y e a r s$ and $11.9 \%$ have stayed for less than 1 year. Most of our respondents are from the internal control department (68.2\%) and the rest belong to the management group (31.8\%). This choice is based on the fact that there are the group of organization members who are in the know of the organizational practices in the organization.

Table 2: Information on risk assessment

\begin{tabular}{|c|c|c|c|c|c|c|c|c|c|c|c|}
\hline \multirow{2}{*}{\multicolumn{2}{|c|}{ S/NO }} & SA & \multicolumn{2}{|l|}{$A$} & \multicolumn{2}{|l|}{$\mathrm{U}$} & \multicolumn{2}{|l|}{$\bar{D}$} & \multicolumn{2}{|l|}{ SD } & \multirow[t]{2}{*}{ MEANS } \\
\hline & & $\mathrm{F} \quad \%$ & $\mathrm{~F}$ & $\%$ & $\mathrm{~F}$ & $\%$ & $\mathrm{~F}$ & $\%$ & $\mathrm{~F}$ & $\%$ & \\
\hline 1 & $\begin{array}{l}\text { Business objectives are } \\
\text { established, } \\
\text { communicated and } \\
\text { monitored and } \\
\text { employees have an } \\
\text { understanding of } \\
\text { company overall } \\
\text { strategy. }\end{array}$ & $\begin{array}{l}7 \\
1.66\end{array}$ & 13 & 3.08 & 51. & 12.1 & 275 & 65.3 & 75 & 17.8 & 2.0546 \\
\hline 2. & $\begin{array}{l}\text { There is a process in } \\
\text { place to periodically } \\
\text { review and update entity } \\
\text { wide strategic plan which } \\
\text { is reviewed and } \\
\text { approved by BOD }\end{array}$ & $4 \quad 10$ & 16 & 3.8 & 55 & 13.1 & $\begin{array}{l}245 \\
58.2\end{array}$ & & 101 & 24.0 & 1.9952 \\
\hline 3 & Strategic plan include I.T & $\begin{array}{l}111 \\
26.4\end{array}$ & $\begin{array}{l}268 \\
63.7\end{array}$ & & 38 & 90 & $\begin{array}{l}3 \\
0.71 \\
\end{array}$ & & 1 & .23 & 4.1544 \\
\hline 4. & $\begin{array}{l}\text { A separate plan } \\
\text { addresses technology }\end{array}$ & $\begin{array}{l}99 \\
23.5\end{array}$ & $\begin{array}{l}245 \\
58.2\end{array}$ & & 65 & 15.4 & 8 & 1.9 & 4 & .95 & $\begin{array}{l}4.0142 \\
5\end{array}$ \\
\hline
\end{tabular}


INTERNATIONAL JOURNAL OF ACADEMIC RESEARCH IN BUSINESS AND SOCIAL SCIENCES Vol. 8, No. 7, July 2018, E-ISSN: 2222-6990 @ 2018 HRMARS

\begin{tabular}{|c|c|c|c|c|c|c|c|c|c|c|}
\hline & $\begin{array}{l}\text { need to meet strategic } \\
\text { plan }\end{array}$ & & & & & & & & & \\
\hline 5 & $\begin{array}{l}\text { There is adequate } \\
\text { mechanism for } \\
\text { identifying business risk. }\end{array}$ & $\begin{array}{l}12 \\
2.9\end{array}$ & 12 & 2.9 & 72 & 17.1 & $\begin{array}{l}242 \\
57.5\end{array}$ & & 2.6 & 2.1448 \\
\hline 6 & $\begin{array}{l}\text { There is periodic risk } \\
\text { assessment. }\end{array}$ & - & 16 & 3.8 & 40 & 9.5 & $\begin{array}{l}263 \\
62.5\end{array}$ & 102 & 24.2 & 1.9287 \\
\hline 7 & $\begin{array}{l}\text { Management considers } \\
\text { how much risk it is } \\
\text { willing to accept and } \\
\text { tries to maintain risk } \\
\text { within this level. }\end{array}$ & $\begin{array}{ll}3 & .71\end{array}$ & $\begin{array}{l}5 \\
1.18\end{array}$ & & 51 & 12.1 & $\begin{array}{l}231 \\
54.9\end{array}$ & 131 & 31.1 & 1.8551 \\
\hline 8 & $\begin{array}{l}\text { BOD and audit } \\
\text { committee oversees and } \\
\text { monitor risk } \\
\text { management processes } \\
\text { and also addresses risk } \\
\text { identified. }\end{array}$ & $\begin{array}{ll}4 & 1.0\end{array}$ & 53 & 12.6 & 47 & 11.2 & $\begin{array}{l}24 \\
50.8\end{array}$ & 103 & 24.5 & 2.1473 \\
\hline 9 & $\begin{array}{l}\text { Changes and their } \\
\text { possible significant } \\
\text { effects are reported }\end{array}$ & - & 12 & 2.9 & $\begin{array}{l}109 \\
25.9\end{array}$ & & $\begin{array}{l}236 \\
56.1\end{array}$ & 64 & 15.2 & 2.1639 \\
\hline $\begin{array}{l}1 \\
0\end{array}$ & $\begin{array}{l}\text { Budget/ forecast are } \\
\text { updated during the } \\
\text { years }\end{array}$ & $\begin{array}{l}108 \\
25.7\end{array}$ & $\begin{array}{l}247 \\
58.7\end{array}$ & & $\begin{array}{l}54 \\
12.8\end{array}$ & & $\begin{array}{l}10 \\
2.37\end{array}$ & 2 & .47 & 4.0665 \\
\hline $\begin{array}{l}1 \\
1\end{array}$ & $\begin{array}{l}\text { Management report } \\
\text { changes that may have } \\
\text { significant effect to BOD } \\
\text { and audit committee. }\end{array}$ & $\begin{array}{l}112 \\
26.6\end{array}$ & $\begin{array}{l}266 \\
63.2\end{array}$ & & 32 & 7.6 & 1.9 & 3 & .71 & 4.1306 \\
\hline $\begin{array}{l}1 \\
2\end{array}$ & $\begin{array}{l}\text { There is a process in } \\
\text { place to identify and } \\
\text { address changes in } \\
\text { reporting regulation and } \\
\text { to approve changes in } \\
\text { accounting as a result of } \\
\text { such change. }\end{array}$ & $\begin{array}{l}112 \\
26.6\end{array}$ & $\begin{array}{l}249 \\
59.1\end{array}$ & & $\begin{array}{l}30 \\
7.12\end{array}$ & & 112.61 & 19 & 4.51 & 4.0071 \\
\hline & & & & & & & & & & 2.8808 \\
\hline
\end{tabular}

KEY: SA ==Strongly Agree, $A==$ agree, $U$ == Undecided, $D==$ Disagree,

SD ==Strongly Disagree. $F==$ Frequency,

Mean $>3=$ Positive Mean. Mean<3 =Negative Mean.

Information on Risk Assessment processes

Table 2 present descriptive statistics on the response to the risk assessment practices of the organizations under study. From the analysis, $65.3 \%$ disagree and $17.8 \%$ strongly disagree that organizations establish and communicate business objective and that employees have an 
understanding of company overall strategy. It can be seen in the mean value which is 2.0546 . From statistics,58.2\% disagree and $24.0 \%$ strongly disagree that most organizations put a process in place to periodically review and update entity-wide strategic plans which have been reviewed and approved by BOD. The mean value confirms this at 1.9952. The analysis also shows that the strategic plan of most firms include I.T. $26.4 \%$ and $63.7 \%$ of the firms studied strongly agree and agree respectively and a mean value of 4.1544 confirms this, and they also have separate strategic plans which address technology need to meet strategic plan. $23.5 \%$ strongly agree and $58.2 \%$ agree and the mean value also supports this (4.0142). Statistical analysis also shows $57.5 \%$ and $22.6 \%$ disagree and strongly disagree respectively that most organization put in place mechanism for identifying business risk. A mean value of 2.0024 supports this. In effect, there is no periodic risk assessment.

The analysis also shows that $54.9 \%$ and $31.1 \%$ disagree and strongly disagree that management considers how much risk it is willing to accept in other to maintain risk within this level. This is shown in the means value which is 1.8551 (less than 3 ). The analysis shows that $50.8 \%$ disagree and $24.5 \%$ strongly disagree that the BOD and audit committee oversee and monitor risk management process and addresses identified risk. The analysis also shows that budget/forecast are updated during the year, $25 \%$ and $58.7 \%$ strongly agree and agree respectively with a mean value supporting these percentages at 4.0665 . Statistics show that $26.6 \%$ strongly agrees and $63.2 \%$ agree that management reports changes that may have a significant effect on the BOD and the audit committee. This is supported by the mean value of 4.1306 . The analysis also shows that $26.6 \%$ strongly agree and $63.2 \%$ agree that most organizations have a process in place to identify and address changes in reporting regulation and approve changes in accounting as a result of such changes. This is also supported by the mean value of 4.0071 . From the result, it can be deduced that our organization has not really adopted the culture of risk assessment. They do not have the habit of establishing business objectives which are communicated even to the employees which will serve as a working guide. There is no culture of establishing business risk which management considers and decides if they will accept or not. Since there is no process to establish business risks the BOD and audit committee does not have a duty of overseeing a process that is not in place. However most organizations do well in the I.T planning, they are often strategic plan to handle I.T. There also seem to be a budgetary system in most organization and variations are reported. However, the overall mean (2.8808) which is less than 3 shows that the risk assessment processes in our organizations are not adequate.

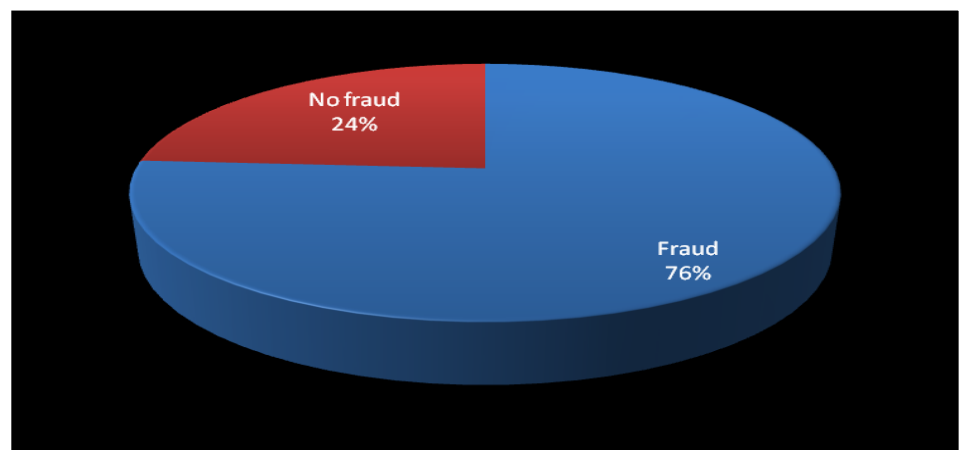

Fig. 1 Percentage of organizations where fraud occurred Source: researcher.

Table 3: Result of logistic regression analysis 
INTERNATIONAL JOURNAL OF ACADEMIC RESEARCH IN BUSINESS AND SOCIAL SCIENCES Vol. 8, No. 7, July 2018, E-ISSN: 2222-6990 @ 2018 HRMARS

Variables in the Equation

\begin{tabular}{|ll|r|r|r|r|r|r|r|r|}
\hline & & & & & & & & \multicolumn{2}{|c|}{$95.0 \%$ C.I.f or EXP(B) } \\
\cline { 7 - 10 } & & B & S.E. & Wald & df & Sig. & Exp(B) & \multicolumn{1}{c|}{ Lower } & Upper \\
\hline Stap & Risk(1) & -.754 & .348 & 4.697 & 1 & .030 & .470 & .238 & .930 \\
\hline
\end{tabular}

a. Variable(s) entered on step 1: Risk.

The result of the analysis shows that risk assessment is positively and significantly related to fraud prevention in Nigerian quoted companies $(p=0.030, O R=0.470, C . I=0.238-0.930)$. Risk assessment as part of the internal control process in corporate governance increases fraud by a multiplicative factor of 0.470 . This implies that risk assessment reduces fraud significantly. Hence the null hypothesis was rejected.

\section{Discussion of Findings}

From our findings, it can be seen that risk assessment has not become a corporate culture. Most organizations just undertake the budgetary processes. The practice of risk assessment has not yet become a corporate practice and that may be the reason for widespread fraud (76\% of the organizations studied have experienced fraud) in their organisation. This will subsequently affect performance. This finding is in tandem with earlier studies of Ping \& Muthulveloo (2015) who found ERM among other factors to significantly influence firm performance. Cheplel (2013) also found that there was a positive and significant relationship between ERM and firm performance.

\section{Conclusion}

There is indeed a great need for our firms to adopt these new practices of ERM. Our businesses are becoming more dynamic and complex. There are expansions of business branches which is characterized by stiff competition, new products are being launched, and there is a heavy reliance on the electronic platform to meet up with service delivery. All these are welcomed developments, but it calls for improved safety of organizational resources to ensure sustainability. The agents (management and board) saddled with the operations and success of these organizations must make sure they deliver and maximize capital invested. This can be achieved through embedding ERM in the fabric of the organizations.

\section{Recommendation}

From the foregoing, it can be seen that there is a need for attention to be paid to the ERM practices in Nigerian firms. Legislations should be put in place to mandate organizational practice of ERM guidelines. Voluntary compliance is encouraged but this has not yielded the required benefits. Therefore appropriate sanctions should be applied through the regulatory bodies to ensure compliance.

The regulatory bodies should be involved in the appointment of board members. They should endeavour to appoint very knowledgeable people into the audit committee who will be proactive in their oversight functions and ensure that ERM processes are installed in our organizations.

\section{Contribution}

This study was spurred by the desire to explore the extent of compliance with the organizational internal control regulations following the huge incidence of fraud in Nigeria and around the world. 
INTERNATIONAL JOURNAL OF ACADEMIC RESEARCH IN BUSINESS AND SOCIAL SCIENCES

Vol. 8, No. 7, July 2018, E-ISSN: 2222-6990 @ 2018 HRMARS

The contribution of this study is mostly to enhance knowledge of the impact and the need for an effective enterprise risk assessment and risk management processes. The study reinforced the need for Nigerian organizations to adhere to the recommendations on internal control such as SOX and the Turnbull report.

\section{References}

Brenriam, N. M., \& Solomon, J. (2008). Corporate governance accountability and mechanisms of accountability: an overview accounting. Auditing and Accountability Journal 21 (7), 885-906

Committee of Sponsoring Organizations of the Treadway Commission. (2004). Enterprise Risk Management - Integrated Framework, New York: COSO.

Demidenko, E., \& McNutt, P. (2010). The ethics of enterprises risk management as a key component of corporate governance. International Journal of social economic,37(10), 802-815

Economic and Financial Crimes Commission. (2014).Internal report.

Goodwin-Stewart, J., \& Kent, P. (2006). The Use of Internal Audit by Australian Companies, Managerial Auditing Journal, 21, 1: 81-101.

Law, P. (2011) Corporate governance and no fraud occurrence in organizations. Managerial Auditing Journal 26(6), 501-518.

Nagy, A. L., \& Cenker, W. J. (2002).An assessment of the newly defined internal audit fraud. Managerial Auditing Journal. 17 (3)130-132

Nigerian Stock exchange fact book. (2014/15).

Nigerian Bureau of statistics and Economic and financial crime commission. (2007). Survey on crime and corruption and awareness, Nigeria: EFCC

Page, M., \& Spira, L.F., (2004). The Turnbull report, internal control and risk management: the developing role of internal audit. Institute of Chartered Accountants of Scotland

Pathak, J. (2005). Risk management, Internal control and Organizational Vulnerabilities. Managerial Auditing Journal 20 (6), 569-577.

Ping, I. P., \& Muthuveloo, R. (2015).The Impact of Enterprise Risk Management on Firm Performance: Evidence from Malaysia, Asian social science journal 11(22).

Shapirro, S. P. (2005). Agency theory. Retrieved from 197:253.4.164.

Smallman C. (1996). Risk and Organizational Behaviour; A research model.Disaster prevention and management 5(2), 12-26.

Soh, D. S. B., \& Martinous, B. N. (2011). The internal audit function perceptions of internal audit roles, effectiveness and evaluation. Managerial auditing journal 26(7), 605-622

Solomon, D. (2008). Perspectives on the current environment and risk management. The Conference Board, Enterprise Risk Management Conference

Spira, L. F., \& Page, M. (2002). Risk Management the Reinvention of Internal Control the changing role of Internal Audit Accounting. Auditing and Accountability Journal 16 (4), 640-661

Stewart, G. J., \& Kent, P. (2006). The use of internal audit by Australian companies. Managerial Auditing Journal 21(1), 81-101

Turnbull, N. (1999).Internal control, guidance for directors on the combined code. London Institute of chartered accountants in England and Wales.Accounting HorizonsSupplement 37-48

Zaman, M. (2001). Turnbull - Generating Undue Expectations of the Corporate GovernanceRole of Audit Committees, Managerial Auditing Journal, 16, 1: 5-9.

Zwaan L., Steward, J., \& Subramanian, N. (2011). Internal Audit involvement in enterprise risk Management. Managerial Auditing Journal 26 (7), 586-604. 